\title{
Energy audit and waste heat recovery system design for a cement rotary kiln in
} Ethiopia: A case study

\author{
T.T. Ayu', M.H. Hailu1, F.Y. Hagos ${ }^{2,3, *}$ and S.M. Atnaw ${ }^{4}$ \\ ${ }^{1}$ Ethiopian Institute of Technology -Mekelle, Mekelle University, Mekelle, Ethiopia \\ ${ }^{2}$ Automotive Engineering Research Group, Faculty of Mechanical Engineering, \\ Universiti Malaysia Pahang, Pekan, Pahang, Malaysia \\ *Email: ftwi@ump.edu.my \\ Phone: +6094246367; Fax: +6094242226 \\ ${ }^{3}$ Automotive Engineering Centre, Universiti Malaysia Pahang, Pekan, Pahang, Malaysia \\ ${ }^{4}$ Faculty of Engineering Technology, Universiti Malaysia Pahang, \\ Gambang, Pahang, Malaysia
}

\begin{abstract}
This paper deals with the energy audit and heat recovery system modeling and design, taking a cement factory in Ethiopia as a case study. The system is a dry type rotary kiln equipped with a sixth stage cyclone type preheater, pre-calciner and grate cooler. The kiln has a capacity of 3,000 tons/day. The energy auditing has been performed based on the data collected from control volume of the kiln system for a ten-month period. The result shows that $25.23 \%$ of the total heat input is released to the environment through the preheater and another $15.58 \%$ through the cooler exhausts. The west heat recovery system (WHRS) can produce a gross power of 5.26 MW as long as the kiln is in operation. The generated power can cover all the electrical energy consumption of the kiln system whether there is a power supply from the grid or not. Therefore, the company can save up to $536,222.10$ USD per year due to the production of clinker using their own power source and avoiding the loss sustained by the company due to power interruption from the grid.
\end{abstract}

Keywords: Energy audit; waste heat recovery; rotary kiln; clinker.

\section{INTRODUCTION}

World demand for cement has been growing rapidly for the last 20 years, especially in newly industrialized countries like China and India. Turkey and Brazil have also contributed a significant amount for the growth rate; also, developed countries like United States and Japan have modest increase but they have considerable shares in the total global cement production [1]. Table 1 shows the top 15 cement-producing countries and their production in Metric ton in 2012. The global cement demand has doubled from 1.8 billion tons in 2002 to 3.7 billion tons in 2012 [2]. Production of cement is one of the most energy intensive process which consumes on average between 4 to 5 GJ per ton of cement [3-6]. This accounts to a consumption of about $12-15 \%$ of the total industrial energy use [7]. Before discussing the energy consumption distribution in the cement production, it is better to explain the production process to have an understanding of the main components of the cement production process. Figure 1 shows a schematic flow diagram of the dry cement production process. The cement production process is generally grouped into six major sub-processes, namely mining, raw material preparation (crushing, stacking, and reclaiming of raw materials), raw meal processing (raw mill 
drying, grinding, and homogenization), clinkerization, cement grinding and storage, and packing $[8,9]$. Raw materials such as limestone, sand (silica), shale, iron ore and others are extracted from the quarry and transported to the raw material crusher. The crushed raw materials are transported to the raw material storage where the raw material loading station filters and stores it separately. The raw material proportioning machine (reclaiming) loads the different raw materials based on the requirement of feed from the central control room (CCR). The proportioned raw material is dried, homogenized and fine-grounded to the required size by the raw mill. The drying process is supported by the hot air from the preheater. The separator at the end of the grinding chamber of the raw mill separates course and fine material, returning the course material back to the raw mill while the fine material is transported with the hot gas in to the multi-stage cyclones. The fine material collected from the cyclone is further lifted by the aerosol and passed through an electrostatic precipitator for the separation of the raw meal from the hot gas. Finally, the raw meal is transported to the raw meal silo $[8,10]$.

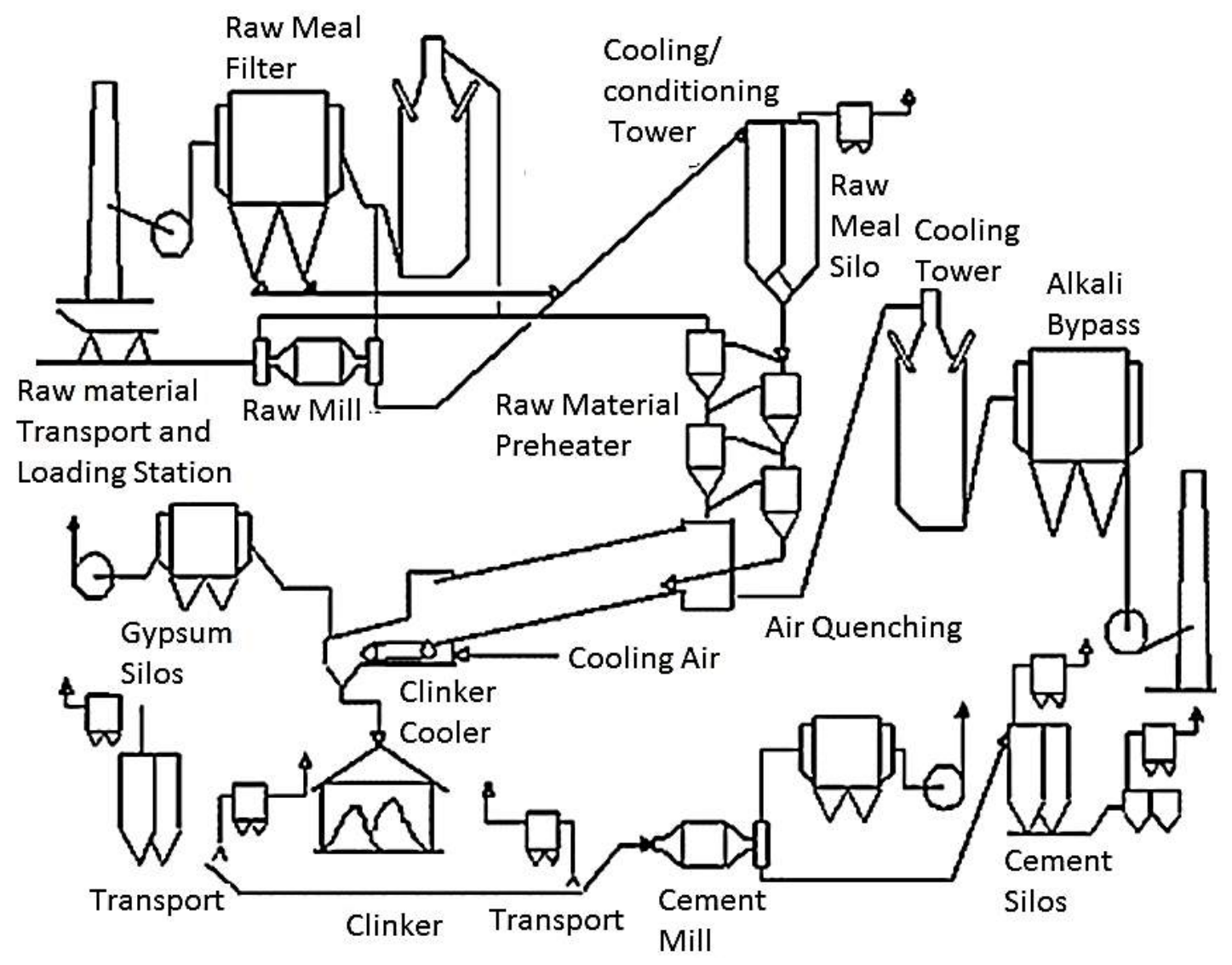

Figure 1. Typical schematics of the dry cement production process [11].

The fourth sub-process in the cement manufacturing process is clinker production. While the other sub-processes depend on the electrical source of energy, this sub-process is mainly dependent on fossil or biomass based fuels. This sub-process constitutes multistage cyclone preheater, calciner (combustion chamber), riser duct, rotary kiln, and grate cooler as shown in Figure 2. The hot gas from the calciner and kiln preheat the feed in the multi-stage cyclone preheaters. The preheated feed starts its first calcination in the calciner while a complete calcination is attained in the kiln. The temperature of the feed inside the kiln reaches up to $1400^{\circ} \mathrm{C}$. The clinker from the kiln is then transported to the 
grate cooler to cool the clinker. The cooled clinker is then transported to the clinker concrete silo for storage. The current study focuses on this sub-process [9].

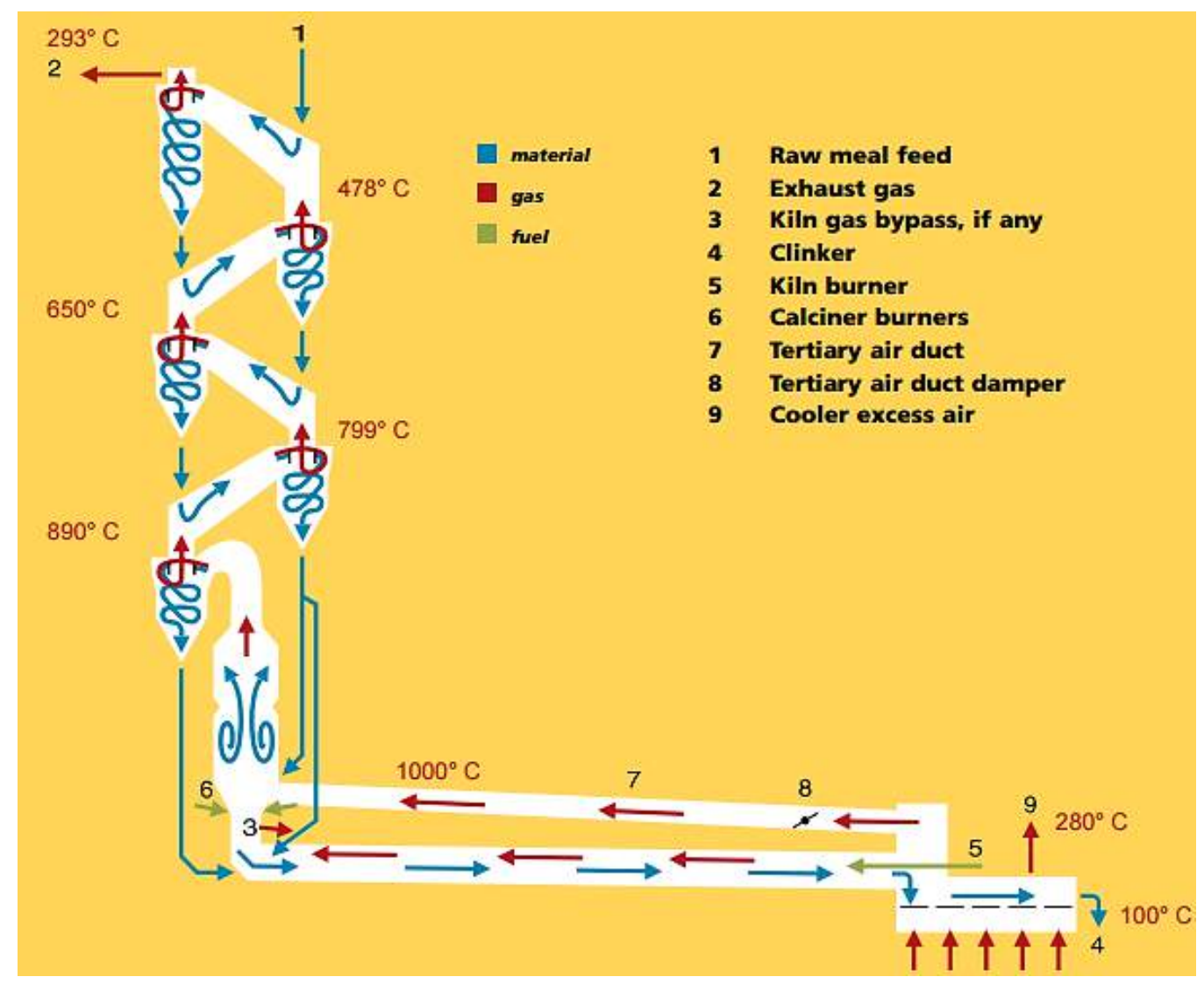

Figure 2. Typical clinker production sub-process[12].

Typically, 30-40\% of the total production cost in cement industries accounts for energy costs $[7,13]$. This cost is estimated at 50 to $60 \%$ of the total cost by Panicker and Sandhya [14]. This high energy demand is mainly due to the need for calcinations and clinker formation at a higher temperature [1]. The ratio of fossil fuel to electrical energy consumption in the modern cement technologies is 4 to 1 [7,15-17]. While calcination and clinker formation are the most thermal energy intensive processes, raw material and cement mills and the auxiliary equipment take the major share in the electrical energy consumption. Summary of the electrical and fossil fuel (thermal energy) flow in cement production is presented by Madlool et al. [7]. Out of the 75\% thermal energy consumed in the cement production process [13], 35\% of it is lost to the environment as waste heat $[10,15,17]$. This concern is not just limited to the production cost, but also to the consequence on the global warming and pollution, which is the biggest challenge of the $21^{\text {st }}$ century. Cement production is one of the major contributors of $\mathrm{CO}_{2}$ [3]. The fact that many cement factories are inclining to the cheapest energy source, coal [18] has become the major source of $\mathrm{CO}_{2}$, accounting to $73.5 \%$ of total power emission [19, 20]. With a proper study, design and policy, there is an appreciable saving potential of energy and thereby in $\mathrm{CO}_{2}$ emission $[5,21]$.

There are different efforts being done to improve the energy consumption of cement industry, thereby improving productivity and reducing emissions per tonne of cement production. The most successful actions so far are the energy conservation and 
waste heat recovery system (WHRS). Since the 1980s, Japanese cement production companies pioneered the introduction of WHRS [22]. WHRS is a proven technology that uses Rankine-cycle steam-based power cycle, Organic Rankine Cycle (ORC) power cycle, Kalina cycle [22-25] or with an advanced cycle such as supercritical $\mathrm{CO}_{2}$ power generation cycle [23]. While the WHRS is a proven technology, it has not been widely used in cement industries except for raw material and fuel drying [24]. China is the leading installer of WHRS in the cement industry with up to 700 installation from its first installation in 1998 to 2012 [22]. According to the report by International Finance Corporation [22], the suspension preheater stages, cooler air volume and recuperation efficiency are the influential parameters in the design of WHRS for a cement production plant [22]. A typical suspension preheater kiln with a precalciner (NSP kiln) has kiln exhaust temperature ranging from 280 to $450^{\circ} \mathrm{C}$, cooler air temperature 250 to $330^{\circ} \mathrm{C}$. Temperatures from as low as $80^{\circ} \mathrm{C}$ to as high as $300^{\circ} \mathrm{C}$ from the processes can be recovered by different technologies [26]. A typical 3,000 tonne of clinker per day capacity plant produces 130,000 and $170,000 \mathrm{Nm}^{3} / \mathrm{h}$ of grate cooler air and kiln exhaust, respectively. With a power conversion efficiency of $18-25 \%$, a typical cement plant can generate 6-9 MW of electricity from the waste heat recovery $[22,23,27,28]$. Priyadarshini and Sivakumar [29] have studied the waste heat recovery of the pyroprocessing unit (preheater, the calciners, the kiln and the clinker cooler) of Dalmia Cement-Unit 2, Trichirapalli, India. The plant capacity in their case study is 3018 tonne per day with a dry type kiln system and four-stage suspension cyclones. For the mass and energy balance analysis, they have used raw material, the air into the cooler and the coal fired into the kiln and the calciners as input and the clinker, the exhaust gases from the preheater and the hot air out from the cooler as output from the pyroprocessing unit. Based on the analysis of their data collection, they have found that the major heat loss sources are kiln exhaust, grate cooler exhaust, preheater gases and kiln surface with percentage heat loss of 19.5, 12.8, 24.4 and 6.1, respectively. The preheat gas and the grate cooler exhaust are found to be suitable for heat recovering with steam generation system with a temperature of $361^{\circ} \mathrm{C}$ and $268^{\circ} \mathrm{C}$, respectively [29].

A modelling case study is studied on the potential of power generation from the WHR of 7100 TPD capacity coal fired cement plant [6]. The temperature of the gases from the cement plant system was in the range of 176 to $330^{\circ} \mathrm{C}$. A supplementary firing was proposed in their study to raise the lower temperature gas exhaust, which was not suitable for the steam generation. Based on their mathematical model based on the combustion and steam power cycle of the cogeneration plant, the cement plant model was able to generate $12.5 \mathrm{MW}$ electric power from the waste heat recovery [6]. A severe power shortage during 2004 in the company has led to initiate a waste heat recovery of a 2500tons-per-day and 5000-tons-per-day capacity plants of Zhejiang Sanshi Cement Co. Ltd. The kiln exhaust gas and the air out from the clinker grate cooler was around $350^{\circ} \mathrm{C}$. In the mid of 2005, the company has generated electricity and is able to provide to grid with an installed capacity of $9 \mathrm{MW}$ [30]. The first cement factory in Ethiopia was established by Italians in 1936 during the five-year fascist occupation of the country. There were four cement plants in 2008 with a combined production capacity of about 2.85 million metric tons per year. According to the 2012 data, there are eighteen cement factories operating in Ethiopia and with an installed production capacity of 11.2 million tons, according to the Ministry of Industry as cited in the weekly newspaper, Reporter [31]. This figure is estimated at 15 million tons according to the Global cement [32]. Table 1 shows the comparison of annual cement production of countries. 
Table 1. Top 15 cement-producing countries in 2012 [2, 31, 32].

\begin{tabular}{lll}
\hline Rank & Country & Production, Mt \\
\hline 1 & China & 2220 \\
2 & India & 247 \\
3 & USA & 74 \\
4 & Iran & 73 \\
5 & Turkey & 69 \\
6 & Brazil & 68 \\
7 & Russia & 60 \\
8 & Japan & 59 \\
9 & Egypt & 55 \\
10 & Saudi Arabia & 53 \\
11 & Indonesia & 53 \\
12 & South Korea & 47 \\
13 & Vietnam & 42 \\
14 & Mexico & 37 \\
15 & Pakistan & 32 \\
16 & Ethiopia & 11.2 \\
\hline
\end{tabular}

Furnace oil, pet coke and coal are mostly used in cement industries but nowadays biomass is being used as an alternative fuel in some countries [33]. Due to this, cement industry is the major emitter of $\mathrm{CO}_{2}$ among the industrial sectors [34]. In Ethiopia, some cement factories use furnace oil while others use imported coal and pet coke. Ethiopia has abundant natural resources potential with more than 45,000 MW from hydropower, around $1070 \mathrm{MW}$ from geothermal resource, 70 million tons coal reserve, 4 TCF (Terra Cubic Feet) of natural gas reserve, 4-6 k Wh/day solar insolation, 3-8 m/s of average wind speed, and also an enormous amount of biomass resources. But still, the basic energy source of the country is wood and hydropower [35]. The energy consumption pattern of Ethiopia is characterized by heavy dependence on biomass fuels and very low level consumption per capita. The national energy balance indicates that traditional biomass fuels (wood, charcoal, agricultural residue and animal waste) accounts about $89 \%$ of the total energy consumption and the rest is $11 \%$ from non-biomass modern sources like electricity and petroleum. Since 1980, the consumption for both traditional and modern energy is growing with a rate of $5 \%$ and $11 \%$ per year respectively. From the total energy consumption, growth for the traditional energy sources in the country the household sector accounts for $88 \%$, but its contribution on the modern energy growth is less than $15 \%$. However, the major increase in petroleum consumption is due to transport, industrial and commercial services sectors [36].

The plant in the current study was using furnace oil. However, financial fluctuation and dependence on import of fossil fuels has caused many interruptions in the production. The company is currently using imported and local coal and also a biomass fueled plant is on the way. The cement plants in the country spend more than $60 \%$ of their cost for energy according to the state minister of industry as cited in the Reporter Newspaper [31]. The current study is aimed at an energy audit to the most energy intensive system of the factory, Kiln and proposing an energy recovery system that is economically feasible with shorter rate of return. 


\section{PLANT DESCRIPTION}

The cement factory under study is one of the biggest cement producing factories in Ethiopia. The plant is installed at an altitude of about 2200 meters above sea level [37]. For the past fourteen years, there was only one production line with a capacity of 900,000 tons of cement per annum. Currently, another new line with a capacity of 1.4 million tons of cement annually has started production. The technology of the second line, which is the main focus of this study and has a capacity of 3,000 ton/day, is dry process rotary kiln equipped with six stage cyclone preheaters and pre-calciner kilns. Shown in Figure 3 is the schematic of control volume of the kiln. The physical appearance of the kiln is refractory lined tubes with a diameter of $4.6 \mathrm{~m}$ and $70 \mathrm{~m}$ length. It is inclined at an angle of $2.3^{\circ}$, and the maximum rotational speed is $4.04 \mathrm{rpm}$ [38]. From the yearly average data recorded in the factory, the specific energy consumption is 3.7 GJ per ton of clinker. Average coal consumption of the kiln system for ten months is 256.8 ton/day or it uses about $125 \mathrm{~kg}$ of coal to produce a ton of clinker, which actually was not consistent throughout the year. Lack of consistency was attributed to the power interruption and the market conditions.

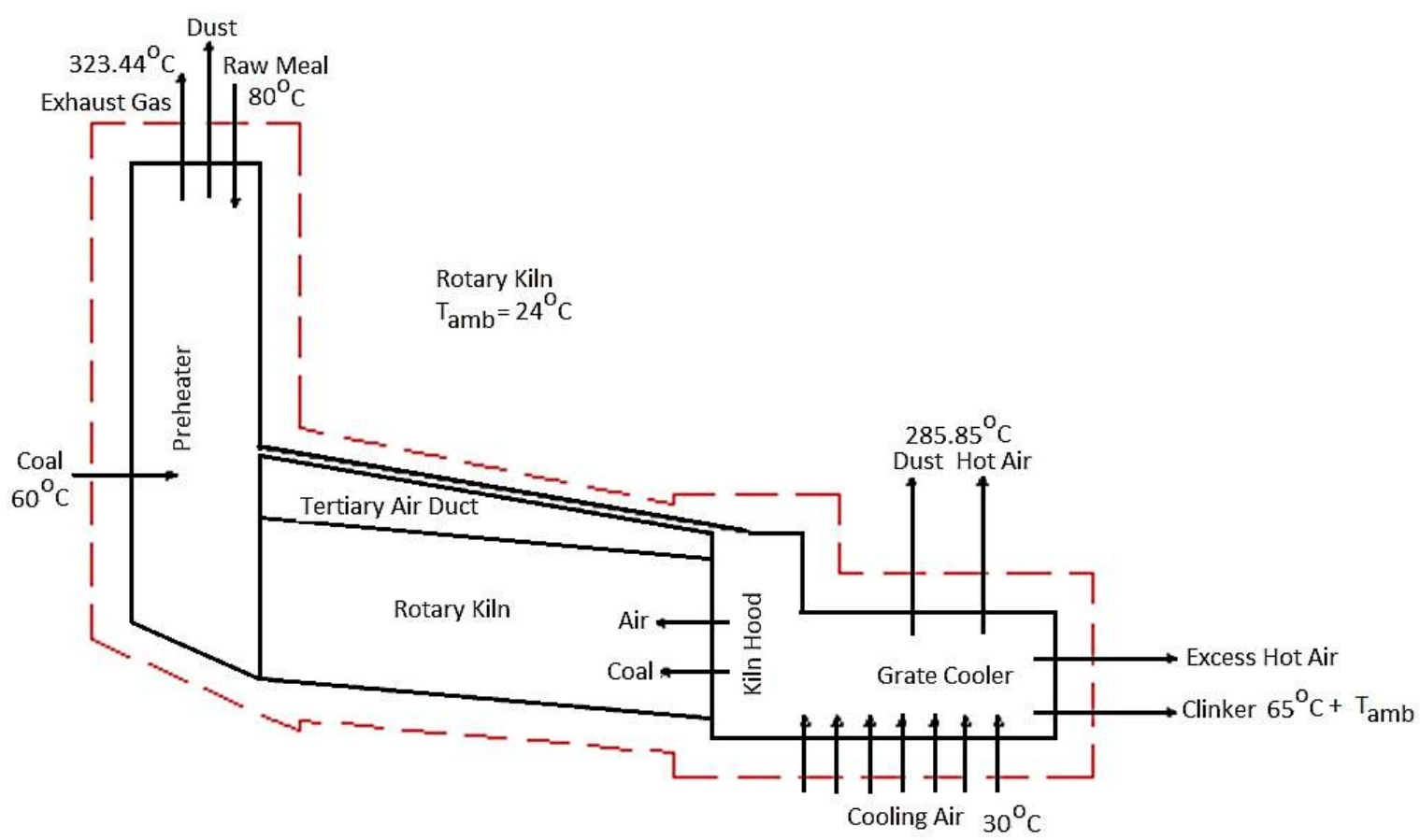

Figure 3. Control volume of the kiln system.

\section{Specific Process Description of the Kiln System}

The raw materials are fed in to the cement production process by homogenization of different types based on the proportion. Raw meal is obtained by grinding the homogenized raw material. The raw meal is pre-heated in cyclone heaters, calcined and sent to the kilns. There are two types of kilns used in cement production, the small-scale vertical type of kilns that are predominantly used in developing countries; and the largesize horizontal rotary type of kilns widely used in industrialized countries. Large-scale rotary kilns are more energy-efficient [39]. The general process description of the kiln system starts with the addition of raw meal from the grinding mill silo to the first cyclone 
and starts to exchange heat with the exhaust gas that goes up from the preheater. As the material goes down, more and more it becomes pre-heated and dried. In addition, homogenization of materials takes place. With this process, the temperature of the material could reach up to $600^{\circ} \mathrm{C}$ and drying and pre-heating take place. The second stage is the pre-calcination in the pre-calciner, which is a secondary device between the preheater and rotary kiln. During this stage, up to $60 \%$ of the total coal in the kiln system burned with an exit temperature of about $850^{\circ} \mathrm{C}$ and around $90-95 \%$ calcinations at the entrance of the kiln. These two stages would actually increase the thermal efficiency of the system by reducing thermal load in the rotary kiln and increasing the output of the system [38].

The material then enters to the inclined rotary kiln for calcination from the feeding slope at kiln end (high end of kiln shell), and a combined movement of material results not only rolls along the circumference, but also axially moves from high end to lower end due to inclination and slow rotation of the kiln shell. At the other end of the kiln, there is a burner with a primary air supply from a blower to burn and increase the temperature and help formation of calcium silicates and the liquid phase at a temperature range of $1,250-1,400^{\circ} \mathrm{C}$. There is also a kiln entrance hood, which is a part that connects rotary kiln and grate cooler. Clinker leaving the kiln is sent into the grate cooler through kiln entrance hood, and secondary air preheated by the grate cooler enters the rotary kiln through kiln entrance hood, and the tertiary air is extracted and conveyed to pre-calciner through the kiln entrance hood. The kiln entrance hood is also a place where fire-watching operation is made, the change of material and flame in the kiln can be observed through the kiln eye on the kiln door and TV fire observation device in order to control the production of the rotary kiln from the central control room (CCR). Cooling of clinker leaving the kiln takes place within horizontally driven grate cooler supplied by fourteen cooling air blowers, in which crystallization of calcium aluminates and calcium ferrite occurs in the temperature range of $1,350-1,200^{\circ} \mathrm{C}$. The temperature of the clinker at the inlet is about $1400^{\circ} \mathrm{C}$ and it reduces to $65^{\circ} \mathrm{C}$ plus the ambient temperature at the outlet.

\section{Opportunity and Problem Identification}

On the kiln system, it is obvious to have some heat losses on the surfaces of kiln shell, calciner, tertiary air duct, preheater and cooler. Surface temperatures are a function of conductivity of refractory used and type of coating in the burning zone of the kiln. The heat losses are through convection and radiation, which can be recovered through different measures. This will reduce the input energy requirement of the system since much of the production cost goes to the purchase of coal. Hence, this will have a positive impact for the factory. Also, using less coal means decreasing the negative environmental impact of the system. There are different possibilities that exist in the cement production process to catch the heat that would somehow or another be squandered to the environment and use it to harness power. The clinker cooler discharge and the kiln preheater exhaust gas are the most accessible and most cost effective waste heat losses available [39]. Both the exhaust gas from the kiln and the air discharged from the cooler stack temperature are on average greater than $305^{\circ} \mathrm{C}$ and $250^{\circ} \mathrm{C}$, respectively. These two heat sources can be connected to a waste heat recovery steam generator (WHRSG). A steam collected from both WHRSG can be combined in a mixing chamber and the steam would be used to power a steam turbine. The power harnessed by the steam turbine as a form of electricity would replenish a portion of the purchased electricity from the grid, thereby reducing the electrical demand from the national grid. 


\section{Data Acquisition}

Data from the plant were recorded on the log sheet in the CCR starting from its operation. This data include most of the necessary inputs and outputs for energy auditing, but there are some data that were not listed on the log sheet. Hence, these data were collected by measuring using infrared thermometer for the surface temperature of the kiln, thermocouples for the temperature of the kiln exhaust gases as well as grate clinker cooler air and pitot static probe with manometer for the exhaust, in addition to air flow measurements during the study period, while some data were directly recorded from the CCR control display. The secondary data were collected carefully so as to be representative of all weather conditions of the factory site. A majority of the data was collected with a sampling rate of every one hour. Variable feed rates were also taken in to consideration. But the primary data collections were taken place only during the study period due to time constraint.

\section{Materials and Energy Balance}

All the input and output materials are identified and measured. Data from the log sheet can represent all the weather conditions and different feed rates but the data taken during the study period can represent only the conditions within a two-month period. So, to make the data fair for evaluation, all the input and output parameters are converted per kilogram of clinker basis. Finally, the material balance is done. Table 2 shows the details of the mass balance of the control volume. The materials considered in the input side are the raw material, fuel, cooler, primary fuel conveying, blasting and false air. The materials considered in the output side are clinker, hot air from cooler grate, dust from cooler, preheater hot gas, preheater dust and excess hot air coming with clinker. The same procedure has been used for the energy and material balance elsewhere [29].

The heat input to the system per kilogram of clinker was calculated based on the input parameters, like sensible heat of air, coal, raw meal and the heat due to calorific value of coal. For the calculation of heat output, the energy consumed for the formation of clinker, the heat discharged with the clinker and dust, the latent heat of evaporation of moisture in the coal and raw material, the heat loss from preheater exhaust and cooler vent as well as the radiation and convection heat losses on the system were calculated. After all these are found, the energy balance is done and the major heat loss areas that could be a useful input to the heat recovery system design are identified and the efficiency of the system, which is the amount of heat utilized to produce the specified amount of clinker out of the total heat input, is known. Table 3 shows the heat input percentage analysis of system per kilogram of clinker. As can be seen from Table 4, the major heat losses are through preheater exhaust (kiln exhaust) and cooler stalk calculated as $25.23 \%$ and $15.58 \%$, respectively. A similar audit by Virendra et al. [40] found 25\% through the preheater and 13\% through cooler exist air [40]. This shows that opportunities to utilize the waste heat through a heat recovery system are in these locations. From the above heat input and output values, the kiln system has an efficiency of $46.22 \%$. The Sankey diagram on Figure 4 describes the energy flow of the whole system. 
Table 2. Materials in and out of the system.

\begin{tabular}{|c|c|c|c|c|c|}
\hline & \multicolumn{3}{|c|}{ Material in } & \multicolumn{2}{|c|}{ Material out } \\
\hline $\begin{array}{l}\text { Item } \\
\text { No. }\end{array}$ & Materials & $\begin{array}{c}\text { Mass in } \\
(\mathrm{kg} / \mathrm{kg} \text { clinker })\end{array}$ & $\begin{array}{c}\text { Total Air to } \\
\text { the System } \\
(\mathrm{kg} / \mathrm{kg} \\
\text { clinker })\end{array}$ & Material & $\begin{array}{c}\text { Mass Out } \\
\text { (kg/kg } \\
\text { clinker) }\end{array}$ \\
\hline 1 & Raw material & 1.566 & & Clinker & 1 \\
\hline 2 & Coal & 0.12 & & $\begin{array}{l}\text { Hot air from } \\
\text { Cooler }\end{array}$ & 1.938 \\
\hline 3 & Cooler air & 3.718 & 5.182 & $\begin{array}{l}\text { Dust from } \\
\text { cooler }\end{array}$ & 0.2296 \\
\hline 4 & Primary air & 0.602 & & $\begin{array}{l}\text { Preheater } \\
\text { exhaust gas }\end{array}$ & 2.69 \\
\hline 5 & $\begin{array}{l}\text { Coal } \\
\text { conveying air }\end{array}$ & 0.03 & & $\begin{array}{l}\text { Dust from } \\
\text { preheater }\end{array}$ & 0.00000742 \\
\hline 6 & Blasting air & 0.000096 & & $\begin{array}{l}\text { Excess hot } \\
\text { air out with } \\
\text { clinker }\end{array}$ & 1.01 \\
\hline 7 & False air & 0.832 & & & \\
\hline & Total & 6.868 & & & 6.868 \\
\hline
\end{tabular}

Table 3. Heat input percentage analysis.

\begin{tabular}{|c|c|c|c|c|c|}
\hline & $\begin{array}{l}\text { Combustion of } \\
\text { coal }\end{array}$ & $\begin{array}{l}\text { Sensible heat of } \\
\text { coal }\end{array}$ & $\begin{array}{l}\text { Sensible } \\
\text { heat of air }\end{array}$ & $\begin{array}{l}\text { Sensible heat } \\
\text { of raw meal }\end{array}$ & Total \\
\hline Equation & $\begin{array}{l}Q_{1}= \\
G C V^{*} m_{\text {coal }}\end{array}$ & $\begin{array}{l}Q_{2}=C_{p} m_{\text {coal }} \\
T_{\text {coal }}\end{array}$ & $\begin{array}{l}Q_{3}=m_{\text {air }} \\
h_{\text {air }}\end{array}$ & $\begin{array}{l}Q_{4}=C_{p} m_{r m} \\
T_{r m}\end{array}$ & \\
\hline $\begin{array}{l}\text { Result }(\mathrm{kJ} / \mathrm{kg} \\
\text { clinker ) }\end{array}$ & $3,372.84$ & 8.62 & 151.84 & 112,11 & $3,645.41$ \\
\hline$\%$ age & 92.52 & 0.24 & 4.17 & 3.08 & 100.00 \\
\hline
\end{tabular}

Where $G V C$ is gross calorific value, $m_{\text {coal }}$ is mass of coal, $T_{\text {coal }}$ is temperature of coal, $m_{\text {air }}$ is mass of air, $h_{\text {air }}$ is enthalpy of air, $C_{p}$ is heat of capacity of raw meal, $m_{r m}$ is mass of raw meal and $T_{r m}$ is temperature of raw mill.

\section{MODEL AND DESIGN OF WASTE HEAT RECOVERY SYSTEM}

The waste heat recovery system is designed based on the two highest waste heat sources, the preheater exhaust gas with $25.23 \%$ and hot air from cooler vent with $15.58 \%$ heat losses. The particular tapping spots are the $3.6 \mathrm{~m}$ diameter exhaust pipe before it gets into the induced draught fan and after the first cyclone from the top for the preheater exhaust and the pipe just after the hot air leaves the grate cooler as well as before it enters the heat exchanger and bag filter for the cooler side. Since the exhaust gas from the preheater is used to dry the raw material and coal before milling and considering the acid dew point temperature of preheater gases, the minimum temperature of the gas should not be less 
than $160^{\circ} \mathrm{C}$ (the temperature at which the vapor condenses is called the acid dew point and typical acid dew points for coal range to about $160^{\circ} \mathrm{C}$ ) [41]. In addition, the flow is assumed to be the same except for some losses due to bends, valves and mechanical equipment, but for ease of calculation, let's assume the flow does not change while passing the boiler. At the end of drying, the temperature of raw material should be $80^{\circ} \mathrm{C}$ and temperature of coal should not be greater than $60^{\circ} \mathrm{C}$ and this could be managed by adjusting the flow. This would actually minimize the excess gas flow that would have been sent to the conditioning tower (air mixing chamber) just only to minimize the temperature before it gets into the electrostatic precipitator.

Table 4. Heat output percentage analysis.

\begin{tabular}{|c|c|c|c|c|}
\hline & & Equation & Result & \%age \\
\hline 1 & Formation of clinker & & 1684.74 & 46.22 \\
\hline \multicolumn{5}{|c|}{$\mathrm{Q}_{\mathrm{s}}=2.22 \% \mathrm{Al}_{2} \mathrm{O}_{3}+5.86 \% \mathrm{~h}_{\mathrm{H}}+6.48 \% \mathrm{MgO}+7.646 \% \mathrm{CaO}-5.116 \% \mathrm{SiO}_{2}-0.59 \% \mathrm{Fe}_{2} \mathrm{O}_{3}$} \\
\hline 2 & $\begin{array}{l}\text { Discharged heat with } \\
\text { clinker }\end{array}$ & $\mathrm{Q}_{6}=\mathrm{C}_{\mathrm{p}, \mathrm{cli}} \mathrm{m}_{\mathrm{cli}} \mathrm{T}_{\mathrm{cli}}$ & 71.09 & 1.95 \\
\hline 3 & $\begin{array}{l}\text { Heat loss due to dust } \\
\text { from cooler }\end{array}$ & $\mathrm{Q}_{7}=\mathrm{h}_{\text {dust, } \mathrm{c}} \mathrm{m}_{\text {dust, } \mathrm{c}}, \mathrm{h}=\mathrm{CpT}$ & 61.51 & 1.69 \\
\hline 4 & $\begin{array}{l}\text { Heat loss due to dust } \\
\text { from preheater }\end{array}$ & $\mathrm{Q}_{8}=\mathrm{h}_{\text {dust,ph }} \mathrm{m}_{\text {dust,ph }}, \mathrm{h}=\mathrm{CpT}$ & 0.0023 & 0.00 \\
\hline 5 & $\begin{array}{l}\text { Evaporation of water } \\
\text { from raw material }\end{array}$ & $\mathrm{Q}_{9}=\mathrm{m}_{\text {water,rm }}\left[\mathrm{C}_{\mathrm{p}}\left(\mathrm{T}_{\mathrm{ph}}-\mathrm{T}_{\mathrm{rm}}\right)+\mathrm{h}_{\mathrm{evap}}\right]$ & 6.956 & 0.19 \\
\hline 6 & $\begin{array}{l}\text { Evaporation of water } \\
\text { from coal }\end{array}$ & $\begin{array}{l}\mathrm{Q}_{10}=\mathrm{m}_{\text {water,coal }}\left[\mathrm{C}_{\mathrm{p}}\left(\mathrm{T}_{\mathrm{ph}}-\mathrm{T}_{\text {coal }}\right)+\right. \\
\left.\mathrm{h}_{\text {evap }}\right]\end{array}$ & 10.96 & 0.30 \\
\hline 7 & Exhaust gas from kiln & $\mathrm{Q}_{11}=\mathrm{C}_{\mathrm{p}, \mathrm{eg}} \mathrm{m}_{\mathrm{eg}} \mathrm{T}_{\mathrm{eg}}$ & 919.65 & 25.23 \\
\hline 8 & Hot air from cooler & $\mathrm{Q}_{12}=\mathrm{m}_{\text {air }} \mathrm{h}_{\text {air }}$ & 567.87 & 15.58 \\
\hline 9 & $\begin{array}{l}\text { Radiation from kiln } \\
\text { surface }\end{array}$ & $\begin{array}{l}\mathrm{Q}_{13}=\sigma \mathrm{e} \mathrm{A}_{\text {kiln }}\left(\mathrm{T}_{\text {kiln,sur }}^{4}\right. \\
\left.\mathrm{T}_{\infty}^{4}\right) / 1000 \mathrm{~m}_{\text {clin }}\end{array}$ & 123.84 & 3.4 \\
\hline 10 & $\begin{array}{l}\text { Convection from kiln } \\
\text { surface }\end{array}$ & $\begin{array}{l}\mathrm{Q}_{14}=\mathrm{h}_{\text {con }} * \mathrm{~A}_{\text {kiln }}\left(\mathrm{T}_{\text {kiln,sur }}-\right. \\
\left.\mathrm{T}_{\infty}\right) / 1000 \mathrm{~m}_{\text {clin }}\end{array}$ & 63.08 & 1.73 \\
\hline 11 & $\begin{array}{l}\text { Radiation from cooler } \\
\text { surface }\end{array}$ & $\begin{array}{l}\mathrm{Q}_{15}=\sigma \mathrm{e} \mathrm{A}_{\text {cooler }}\left(\mathrm{T}_{\text {cooler,sur }}^{4}\right. \\
\left.\mathrm{T}_{\infty}^{4}\right) / 1000 \mathrm{~m}_{\text {clin }}\end{array}$ & 2.15 & 0.06 \\
\hline 12 & $\begin{array}{l}\text { Convection from } \\
\text { cooler surface }\end{array}$ & $\mathrm{Q}_{16}=\mathrm{h}_{\mathrm{con}} * \mathrm{~A}_{\mathrm{c}}\left(\mathrm{T}_{\mathrm{c}, \text { sur }}-\mathrm{T}_{\infty}\right) / 1000 \mathrm{~m}_{\mathrm{clin}}$ & 1.46 & 0.04 \\
\hline 13 & $\begin{array}{l}\text { Radiation from } \\
\text { preheater }\end{array}$ & $\begin{array}{l}\mathrm{Q}_{17}=\sigma e \mathrm{~A}_{\mathrm{ph}}\left(\mathrm{T}_{\mathrm{ph}, \mathrm{sur}-}\right. \\
\left.\mathrm{T}_{\infty}^{4}\right) / 1000 \mathrm{~m}_{\mathrm{clin}}\end{array}$ & 43 & 1.18 \\
\hline 14 & $\begin{array}{l}\text { Natural Convection } \\
\text { from Preheater surface }\end{array}$ & $\begin{array}{l}\mathrm{Q}_{18}=\mathrm{h}_{\mathrm{con}} * \mathrm{~A}_{\mathrm{ph}}\left(\mathrm{T}_{\mathrm{ph}, \text { sur }}-\right. \\
\left.\mathrm{T}_{\infty}\right) / 1000 \mathrm{~m}_{\text {clin }}\end{array}$ & 27.77 & 0.76 \\
\hline \multirow[t]{2}{*}{15} & $\begin{array}{l}\text { Un-accounted heat } \\
\text { losses }\end{array}$ & & 61.33 & 1.68 \\
\hline & Total & & 3645.41 & 100.00 \\
\hline
\end{tabular}




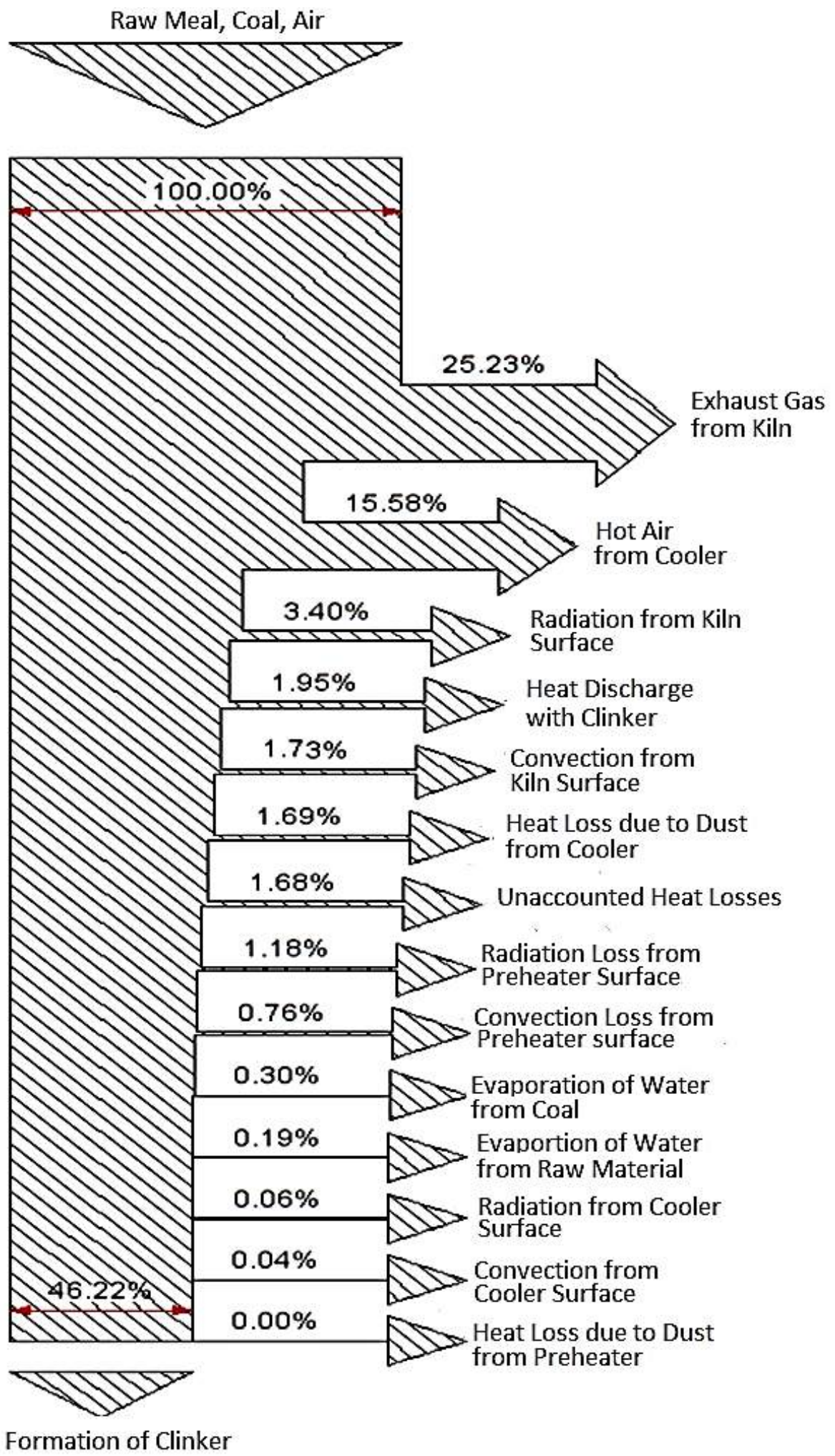

Figure 4. Sankey diagram of energy balance.

The temperature of hot air that exits from the cooler vent and passes through the heat exchanger should have a temperature of less than $200^{\circ} \mathrm{C}$ before it enters the bag filter. However, the temperature can be decreased further using the heat recovery system. If the exit temperature of hot air from the economizer can reach $80^{\circ} \mathrm{C}$, the existing heat 
exchanger between the cooler vent and bag filter will be there only for safety purpose. Generally, the inlet gas temperature from preheater $(\mathrm{PH})$ exhaust to the waste recovery system will be $323.44^{\circ} \mathrm{C}$ and it leaves the system with a temperature of $160^{\circ} \mathrm{C}$. Meanwhile, the inlet air temperature from the cooler vent is $285.85^{\circ} \mathrm{C}$ and the outlet temperature will be $80^{\circ} \mathrm{C}$.

\section{Available Energy from the System}

The available energy that can be harnessed from the preheater exhaust gas and cooler vent hot air can be calculated as shown below.

$$
\dot{Q}_{\text {avialable }}=\dot{Q}_{\text {eg }}+Q_{\text {alr }}
$$

The heat available from preheater exhaust can be calculated from Eq. 2 as:

At a flow of $2.69 \mathrm{~kg} / \mathrm{kg}$ of clinker or $2.00 \mathrm{Nm}^{3} / \mathrm{kg}$ of clinker $\left(218,808 \mathrm{Nm}^{3} / \mathrm{hr}\right)$, the heat available from the $\mathrm{PH}$ exhaust gas will be:

$$
\dot{Q_{e g}}=m_{e g} * \dot{m}_{\text {clinker }}\left[C_{p 1} T_{1}-C_{p 2} T_{2}\right]
$$

where, $C_{p 1 @ T_{1}=323.44^{\circ} \mathrm{C}}=\frac{1.055 \mathrm{~kJ}}{\mathrm{~kg}^{\circ} \mathrm{C}}$ and $C_{p 1 @ T_{2}=160^{\circ} \mathrm{C}}==\frac{1.027 \mathrm{~kJ}}{\mathrm{~kg}^{\circ} \mathrm{C}}$

Therefore, at a flow rate of $2.69 \mathrm{~kg} / \mathrm{kg}$ of clinker the heat is $\dot{Q}_{e g}^{\circ}=14,462.17 \mathrm{~kW}$.

Heat available from cooler vent hot air can be calculated from Eq. 3 as:

The flow of hot air through the cooler vent is $1.938 \mathrm{~kg} / \mathrm{kg}$ of clinker or $1.5 \mathrm{Nm}^{3} / \mathrm{kg}$ of clinker $\left(164,106 \mathrm{Nm}^{3} / \mathrm{hr}\right)$, the available heat will be:

$$
\dot{Q}_{\text {hot air }}=m_{\text {air }} * \dot{m}_{\text {clinker }}\left[h_{\text {air } 1}-h_{\text {air } 2}\right]
$$

where $h_{\text {air1@ } @=285.85^{\circ} \mathrm{C}}=293.02 \mathrm{~kJ} / \mathrm{kg}$ and $h_{\text {air } 2 @ T=80^{\circ} \mathrm{C}}=79.53 \mathrm{~kJ} / \mathrm{kg}$. Hence, at a flow of $1.938 \mathrm{~kg} / \mathrm{kg}$ clinker the heat becomes $Q_{\text {alr }}=12,573.67 \mathrm{~kW}$. Therefore, the total heat available from the cement processing plant is $\dot{Q}_{\text {avialable }}=27,035.84 \mathrm{~kW}$.

When it is assumed that the overall efficiency of the system is to be $90 \%$ of the total available heat will be $\dot{Q}_{\text {avialable }}=24,332.25 \mathrm{~kW}$. However, how much of this available energy can be recovered will be a result of technological advancement of the system or other physical, technical and operational factors. The main thing here is that the heat recovery system should be a type which tolerates a moderate to high dust level so that the existing electrostatic precipitator and bag filter on the plant can be used after the gas and air got out of the boiler of the WHRS.

\section{Heat Recovery Using Integrated System}

The working principle of the integrated system is that both steams from the two heat sources will be mixed and entered into one turbine. This means that with the available temperature, the system can be designed by having a separate boiler for both fluids and the water would first pass through the economizer section of the cooler hot air boiler for preheating, then the water splits with a part going to the evaporator section of the $\mathrm{PH}$ boiler and the rest to evaporator section of cooler boiler and finally the steam rejoins in 
the super-heater section of the PH boiler and enters the turbine. Figure 5 shows the typical schematics of the system. Thermodynamically, the entering water to the condenser will have a temperature of $36^{\circ} \mathrm{C}$, both evaporators will have the same saturated steam temperature of $120^{\circ} \mathrm{C}$ and finally the maximum super-heated steam temperature in the $\mathrm{PH}$ super-heater will be $280^{\circ} \mathrm{C}$. Considering the hot gas and air from the heat sources, the $\mathrm{PH}$ exhaust gas with a temperature of $323.44^{\circ} \mathrm{C}$ gets in to the $\mathrm{PH}$ boiler through the superheater, and then leaves to the evaporator with a temperature of $200^{\circ} \mathrm{C}$. On the other side, the cooler hot air gets in to the evaporator with a temperature of $285.85^{\circ} \mathrm{C}$ and leaves the economizer with a temperature of $80^{\circ} \mathrm{C}$.

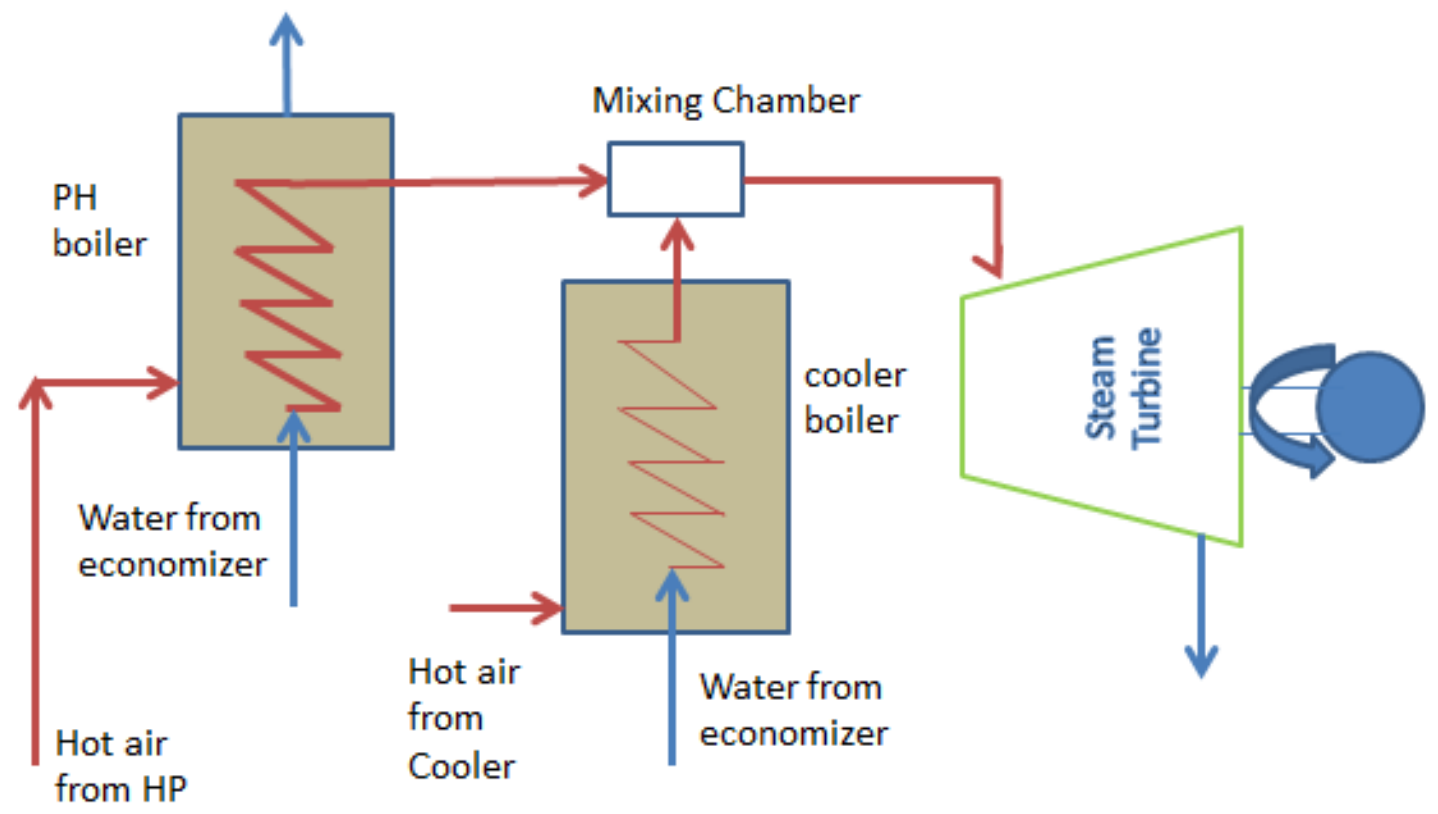

Figure 5. Typical combined system WHRSG plant.

Using a steam table with the given parameters and assuming a $90 \%$ overall system efficiency, the amount of steam produced from the cooler vent will be $\dot{m}_{s 1}=$ $3.93 \mathrm{~kg} / \mathrm{sec}$. Similarly, assuming that all the available heat from the PH exhaust gas is transferred to the steam as a heat input with a $90 \%$ overall efficiency to the system, the amount of steam produced will be $\dot{\mathrm{m}}_{\mathrm{s} 2}=4.52 \mathrm{~kg} / \mathrm{sec}$. The total steam produced is therefore $\dot{\mathrm{m}}_{\mathrm{s}}=\dot{\mathrm{m}}_{\mathrm{s} 1}+\dot{\mathrm{m}}_{\mathrm{s} 2}=8.45 \frac{\mathrm{kg}}{\mathrm{sec}}$.

The net work done by the system is calculated to be:

$$
W_{\text {net }}=W_{T}-W_{P}=\dot{m}_{s}\left(h_{1}-h_{2}\right)=5,258.1 \mathrm{~kW}
$$

This shows that the actual gross power that can be harnessed from the system is about 5.26 MW. Therefore, the efficiency of the system is calculated to be:

$$
\eta_{\text {Rankine }}=\frac{W_{\text {net }}}{\dot{Q}_{\text {hot air }}+\dot{Q}_{\text {eg }}}=21.6 \%
$$

This potential power generation and the calculated efficiency are in line to the ranges given by IFC [22] and Amiri and Vaseghi [23]. Let this system be an air cooled 
one, so the air flow which should be circulating in the sink will be calculated based on the heat output from the condenser from Eq. 4. That is:

$$
Q_{\text {condenser }}=m_{s}\left(h_{2}-h_{3}\right)=m_{a} C_{P a}\left(T_{1}-T_{2}\right)
$$

where, $m_{a}$ - mass of circulating cooling air of the sink, $C_{p w}$ - Specific heat of water $(0.24$ $\left.\mathrm{kcal} / \mathrm{kg}{ }^{\circ} \mathrm{C}=1.005 \mathrm{~kJ} / \mathrm{kg}{ }^{\circ} \mathrm{C}\right), T_{l} \quad$ - Temperature of air leaving the condenser $\left(36.2^{\circ} \mathrm{C}\right)$ and $T_{2}$ - Temperature of cooling air from the cooling tower at inlet of the condenser $\left(20^{\circ} \mathrm{C}\right)$

$$
m_{a}=\frac{m_{s}\left(h_{2}-h_{3}\right)}{C_{P w}\left(T_{1}-T_{2}\right)}=1,171.76 \mathrm{~kg} / \mathrm{sec}
$$

\section{ECONOMICAL FEASIBILITY OF THE RECOVERY SYSTEM}

The economic analysis of the power plant can be addressed in two different ways. First, by calculating the overall plant investment cost and then calculating the payback period depending on the current energy cost in the country from the point of view of energy saving of the system per year. The other way is by investigating the financial loss of the company due to power interruption from the main grid per year to see how much money can be saved in a year using own power source through the heat recovery system designed and calculate the payback period depending on both energy saved per year and direct money saved from power blackout. The best way to estimate the total investment cost is searching for the average or to be safe the maximum cost per $\mathrm{kW}$ generated for the system on a turnkey project basis. Table 5 shows the result of a study conducted by University of California in some of cement factories in China showing investment cost and power generated by operating heat recovery plants.

Table 5. Investment cost of waste heat recovery system of selected cement plants in China [42].

\begin{tabular}{ccccccc}
\hline $\begin{array}{c}\text { I. } \\
\text { NO }\end{array}$ & $\begin{array}{c}\text { Manufactur } \\
\text { ed in }\end{array}$ & $\begin{array}{c}\text { Installe } \\
\mathrm{d} \text { in }\end{array}$ & $\begin{array}{c}\text { Year of } \\
\text { Installati } \\
\text { on }\end{array}$ & $\begin{array}{c}\text { Power } \\
\text { Generated } \\
(\mathrm{kWh} / \mathrm{ton} \\
\text { clinker })\end{array}$ & $\begin{array}{c}\text { Investme } \\
\text { nt Cost } \\
(\mathrm{USD} / \mathrm{k} \\
\mathrm{W})\end{array}$ & Company \\
\hline 1 & Japan & China & 2002 & $39(6 \mathrm{MW})$ & $2250-$ & Anhui Ningguo \\
& & & & & 2750 & United Cement \\
2 & China & China & 2006 & $40(6 \mathrm{MW})$ & 1250 & $\begin{array}{c}\text { Beijing Cement } \\
\text { Ltd. }\end{array}$ \\
\hline & China & China & 2006 & $7.5(\mathrm{in}$ & 800 & \\
& & & MW) & & \\
\hline
\end{tabular}

The study stated that by using the domestic technology in China, they have produced about 24-32 kWh per ton of clinker but the most recent technologies can produce up to $35 \mathrm{kWh}$. The Japanese technology reached $45 \mathrm{kWh}$ per ton of clinker. The investment cost of domestic technology plants in China is about 741 USD per kilo watt of electricity while the foreign technologies cost about 1,975 USD per kilo watt. Running time and required labor are approximately the same. The study was conducted in 2008 and considering a 5\% market fluctuation per year, labor cost and other additional cost differences within the four-year period and taking the foreign technology cost in China, the power generation cost can be approximately estimated to be 2,370 USD per kilo watt 
electricity generated. Energy cost of the current factory under investigation is 0.0211 $\mathrm{USD} / \mathrm{kWh}$ [43]. Initial investment cost or installed capacity cost is calculated to be 2, 466,200 USD.

\section{Annual Energy Saving and Payback Period}

The planned running days in a year for the plant is 270 days. Therefore, annual energy production by the heat recovery system is $E_{P}=34,084,800 \mathrm{kWh} /$ year. Assuming $8 \%$ auxiliary power consumption and loss in the WHRS, the remaining annual energy saved by the system would be $E_{s}=31,358,016 \mathrm{kWh} /$ year. The time required to recover the initial investment is calculated from the annual energy saving. The investment point of view payback period can be calculated in two different approaches:

1. Worst case scenario

2. Most probable case scenario

\section{Worst Case Scenario}

This case scenario is done assuming the only benefit of the WHRS is the annual energy production from the waste heat and the only expense for the system implementation is only the capital investment, it is a simple payback analysis.

$$
\text { Simple Payback Period }=\frac{C_{c}}{E_{S} P_{e}}
$$

where $C_{c}$ - Installed Capacity cost (USD), $E_{S}-$ Annual Energy Saved ( kWh/year) and $P_{e}-$ Unit price of electricity, US $\$ / \mathrm{kWh}$.

$$
\text { Simple Payback Period }=\frac{12,466,200}{0.0211647270 .35}=18.84 \text { years }=229.4 \text { months }
$$

Most steam power plants have a lifetime of 20-30 years. For economical cost analysis of utility investments, 25 years shall be used [44]. But the above simple payback period is about 19 years, which makes the investment unattractive. For this case, the time taken to supply and install the WHRS was not taken into consideration. Similarly, the interest rate of the investment, the operation and maintenance cost were not considered.

\section{Most Probable Case Scenario}

In this scenario, the financial loss due to the power interruption, the interest rate of loan to the investment, energy saving due to grid power replacement, operation and maintenance costs are considered. The factory has lost a considerable amount of production and money due to power source from the grid interruption and fluctuation in the past operation. These losses for the last four years are listed in Table 6 below. The financial loss is calculated depending on the amount of profit level per ton of cement in each physical year. 
Table 6. Financial loss of MBMPP due to electrical power interruption [43].

\begin{tabular}{ccccc}
\hline $\begin{array}{c}\text { Physical } \\
\text { Year }\end{array}$ & $\begin{array}{c}\text { Product } \\
\text { Type }\end{array}$ & $\begin{array}{c}\text { Kiln \& Cement mill Stoppage } \\
\text { Due to EEPCo's Power Supply } \\
\text { Interruption (hr) }\end{array}$ & $\begin{array}{c}\text { Production } \\
\text { loss (ton) }\end{array}$ & $\begin{array}{c}\text { Financial loss } \\
\text { (USD) }\end{array}$ \\
\hline 2008 & Clinker & 236 & 22,691 & $1,066,111.11$ \\
& Cement & 243 & 31,600 & \\
2009 & Clinker & 1009 & 101,912 & $7,832,777.78$ \\
& Cement & 1428 & 194,101 & \\
2010 & Clinker & 2595 & 254,108 & $13,480,555.56$ \\
& Cement & 2070 & 283,542 & \\
& Clinker & 146.01 & $14,303.17$ & $2,889,166.67$ \\
& Cement & 146.82 & 20,002 & \\
& & & Average & $6,317,152.78$ \\
\hline
\end{tabular}

Currently, there are at least three main losses due to power interruption. First, if the power shedding lasts more than two hours, the kiln should go through heating up from 1-2 hours or more depending on the stoppage hour with a $2 \mathrm{ton} / \mathrm{hr}$ feed of coal. Currently, the current cost of coal is $278 \mathrm{USD} /$ ton. Secondly, during the power shedding period, most of the production people will be kept idle while getting paid. So, the company loses some productive time of workers, which will increase the labor cost of the company. The third and major one is the production and financial loss due to plant stoppage. The year to date (YTD) electrical consumption of the kiln system is $39.28 \mathrm{kWh} /$ ton of clinker and the production is $122.81 \mathrm{ton} / \mathrm{hr}$, which means the system consumes about $4.82 \mathrm{MW}$ of electricity, which is almost equal to the net power output of the recovery system (4.84 MW). In the same manner, cement mill I, cement mill II and Packer I consumes 5.66 MW, 4.97 MW and 1.5 MW of electricity, respectively. However, the WHRS can only support the kiln system during power shedding as the clinker is the major component of cement. Having excess clinker production is an advantage for the total production. Assuming that implementation of the waste heat recovery power plant can avoid a minimum of $50 \%$ of the production and financial losses, which are nearly 3,158,576.39 USD. The energy cost per kWh difference between power grid tariff and the energy that is to be generated from the WHRS is calculated using:

$$
C O E=\left[\left(C_{C} * F C R\right)+C_{O \& M}\right] / E_{S}
$$

where, $C O E$ - Cost of Energy, $F C R$ - Fixed charge rate, fraction of installed cost paid for financing institution, which is greater than loan interest rate and greater than $1 / \mathrm{N}$, where $\mathrm{N}=$ total term of financing year and $C_{O \& M}$ - Operation and maintenance cost. Assume that the WHRS system will be implemented using a loan from a bank with a $10 \%$ interest rate. The operation and maintenance cost for the WHRS ranges between 0.002-0.006 USD on different literatures depending on the design type and complication. For this system, $0.004 \mathrm{USD} / \mathrm{kWh}$ is taken. The payback period can be calculated based on both 
the energy saved using the WHRS and considering the economic advantage of the system in avoiding power interruptions. Assuming two years of supply, erection and commissioning of the power plant and $90 \%$ of the loan is to be used in the first year and the remaining $10 \%$ for the next year. As shown in Eq.6, the COE during the payment period is found to be $0.054 \mathrm{USD} / \mathrm{kWh}$ by taking $\mathrm{FCR}=0.125$. This value is higher than the grid power tariff. This is due to the down payment as shown in Table 6 . The payback period is estimated to be 8.20 years or 99.82 months.

For the operation of the WHRS, $31 \mathrm{~m}^{3} / \mathrm{hr}$ feed water supply is required by the system. By taking into consideration of $30 \%$ leakage and loss per hour, $40.3 \mathrm{~m}^{3} / \mathrm{hr}$ water is required. However, the current water treatment plants in the company cannot supply this amount. Therefore, a new treatment plant which can supply the required amount of water must be taken into consideration with the WHRS plant. The water treatment plant in the factory, which was constructed in 2009, has a capacity of $63 \mathrm{~m}^{3} / \mathrm{hr}$ of purified water capacity cost $2,222,222.22$ USD that is $35,273.37 \mathrm{USD} / \mathrm{m}^{3}$. Taking $20 \%$ cost difference between now and then, the costs are estimated to be $42,328 \mathrm{USD} / \mathrm{m}^{3}$. Hence, a water treatment plant with a capacity of $40.3 \mathrm{~m}^{3} / \mathrm{hr}$ purified water will cost 1,705,818.40 USD. This cost can be covered with the positive cost on the ninth year. This could push the payback period to about 9 years or 109.58 months. The COE after the payback period will only be the operation and maintenance cost, which is $0.004 \mathrm{USD} / \mathrm{kWh}$. Energy cost saving per year due to replacement of grid power is calculated as 536,222.10 USD per year. Increasing the annual running hours of the kiln system can increase the energy generated and energy cost saving per year.

\section{CONCLUSIONS}

The net power produced from the system is $4,839.20 \mathrm{~kW}$, which is equal to $159.24 \mathrm{~kJ} / \mathrm{kg}$ of clinker $(4.37 \%)$. This will increase the thermal efficiency of the kiln system from $46.22 \%$ to $50.59 \%$ and also covers $10.75 \%$ of the total electrical power consumption of the plant in to consideration. The standard specific coal consumption for the technology ranges from $730-780 \mathrm{kcal} / \mathrm{kg}$ of clinker. However, the current consumption of the plant as per the data gathered from the CCR during the study period is about $884 \mathrm{kcal} / \mathrm{kg}$ clinker or $3.7 \mathrm{GJ} /$ ton of clinker on average. This shows that there is an excess of about $100 \mathrm{kcal} / \mathrm{kg}$ of clinker or $418.6 \mathrm{~kJ} / \mathrm{kg}$ of clinker of coal consumption on the system.

Producing electricity with own power using waste heat from the process will reduce electrical consumption from national grid supply, which, on the other hand, decreases the cost of clinker production and helps the company to be more competitive in today's unstable market. Using integrated WHRS, the exit temperature at the preheater side will be reduced from $323^{\circ} \mathrm{C}$ to $200^{\circ} \mathrm{C}$ and at the cooler stalk from $286^{\circ} \mathrm{C}$ to $80^{\circ} \mathrm{C}$. A water treatment plant with a capacity of purifying $40.3 \mathrm{~m}^{3} / \mathrm{hr}$ should be incorporated with the WHRS and the condenser should be an air cooled one. Considering the estimated initial investment for the water purification plant, the payback period is calculated to be less than 10 years, indicating its economic feasibility. In addition, during the power interruption period, the company can make use of own generated power to keep the cement mill (3.35 MW) and packer I (1.5 MW) running. The implementation of a WHRS avoids kiln heating up due to power interruption more than 2 hours and saves some money. It also saves the company's productive time around the kiln area during power shedding hours. The company can also save some electrical energy usage to the air mixer and cooling fan that would have been used to cool the exhaust gas and hot air from the preheater and cooler stalk before it enters the electrostatic precipitator and bag filter 
respectively. Because the exhausts are already on the required temperature range after it leaves the WHR system. It is recommended that the government of Ethiopia encourages this WHRS implementation through tax exemption and other incentives, especially in cement industries because this sector is growing fast and there is a good opportunity from the heat that is easily released to the environment without any use. For future work, an energy balance equation is to be developed based on the available data so that a general conclusion could be drawn for similar cement plants elsewhere.

\section{ACKNOWLEDGEMENT}

The authors would like to extend their gratitude to EnPe and Mekelle University for the financial support and facility provision during the data collection process.

\section{REFERENCES}

[1] Wang S, Han X. Sustainable Cement production with improved energy efficiency and emerging $\mathrm{CO}_{2}$ mitigation. Advances in Chemical Engineering and Science. 2011;2:123-8.

[2] Armstrong T. An overview of global cement sector trends. FICEM-APCAC 30th Technical Congress. Lima, Peru. 2013.

[3] Taylor M, Tam C, Gielen D. Energy efficiency and $\mathrm{CO}_{2}$ emissions from the global cement industry. Korea. 2006;50:61-7.

[4] Avami A, Sattari S. Energy conservation opportunities: cement industry in Iran. International Journal of Energy. 2007;1:65-71.

[5] Gholipour Khajeh M, Iranmanesh M, Keynia F. Energy auditing in cement industry: A case study. Energy Equipment and Systems. 2014;2:171-84.

[6] Varma GP, Srinivas T. Design and analysis of a cogeneration plant using heat recovery of a cement factory. Case Studies in Thermal Engineering. 2015;5:2431.

[7] Madlool N, Saidur R, Hossain M, Rahim N. A critical review on energy use and savings in the cement industries. Renewable and Sustainable Energy Reviews. 2011;15:2042-60.

[8] Lafarge. All about Cement. Available: http://www.lafarge.com.eg/wps/portal/ eg/en/2_2_1-Manufacturing_process

[9] Worrell E, Kermeli K, Galitsky C. Energy efficiency improvement and cost saving opportunities for cement making. Environmental Energy Technologies Division, U.S. Environmental Protection Agency In: Agency USEP. 2013; 1-71.

[10] ECC. Cement Industry. Output of a seminar on energy conservation in cement industry: The Energy Conservation Center, Japan; 1994.

[11] Berube RA. Effective temperature control for cement kiln off-gases. Turbosonic. 2011.

[12] FLSmidth. Preheater calciner systems. In: FLSmidth. 2011.

[13] Zeeshan M, Arbab MN. Waste heat recovery and its utilization for electric power generation in cement industry. International Journal of Engineering and Technology. 2015;15.

[14] Panicker SS, Sandhya M. Mathematical Modelling of energy recovery of rotary kiln and forecasting of $\mathrm{CO}_{2}$ emission in the indian cement industry. International Journal of Engineering Research and Development. 2013;6:35-46. 
[15] Khurana S, Banerjee R, Gaitonde U. Energy balance and cogeneration for a cement plant. Applied Thermal Engineering. 2002;22:485-94.

[16] Azad AK, Rasul MG, Mofijur M, Bhuiya MMK, Mondal SK, Sattar MK. Energy and waste management for petroleum refining effluents: A case study in Bangladesh. International Journal of Automotive and Mechanical Engineering. 2015;11:2170-87.

[17] Nawi MRM, Mamat AMI, Ismail H. Numerical heat transfer analysis of waste heat exchanger for exhaust gas energy recovery. Journal of Mechanical Engineering and Sciences. 2015;8:1498-506.

[18] Hailu MH, Hagos FY. Waste heat recovery potential: A case of Messebo cement factory. Royal Insitute of Technology KTH; 2009.

[19] Said MFM, Aroussi A. Utilization of pulverised coal monitoring system for cleaner electricity generation. International Journal of Automotive and Mechanical Engineering. 2014;9: 1588-98.

[20] Said MFM, Aroussi A. Utilization of pulverised coal monitoring system for cleaner electricity generation. International Journal of Automotive and Mechanical Engineering. 2014;9:1588-98.

[21] Hasanbeigi A, Menke C, Therdyothin A. The use of conservation supply curves in energy policy and economic analysis: The case study of Thai cement industry. Energy Policy. 2010;38:392-405.

[22] IFC. Waste Heat Recovery for the Cement sector: Market and supplier analysis. World Bank Group; 2014.

[23] Amiri A, Vaseghi MR. Waste heat recovery power generation systems for cement production process. IEEE Transactions on Industry Applications. 2015;51:13-9.

[24] IETD. Waste Heat Recovery for power generation. Institute for Industrial Productivity. Available: http://www.setatwork.eu/database/products/R197.htm

[25] Bundela P, Chawla V. Sustainable development through waste heat recovery. American Journal of Environmental Sciences. 2010;6:83-9.

[26] Nawi MRM, Mamat AMI, Ismail H. Numerical heat transfer analysis of waste heat exchanger for exhaust gas energy recovery. Journal of Mechanical Engineering and Sciences. 2015;8.

[27] Makky EA, M. Yusoff M. Bioeconomy: Fermented Waste management and pectinases purification from thermomyceslanuginosus. Journal of Mechanical Engineering and Sciences. 2014;7:1196-207.

[28] Abdul Hamid K, Azmi WH, Mamat R, Usri NA, Najafi G. Effect of Temperature on heat transfer coefficient of titanium dioxide in ethylene glycol-based nanofluid. Journal of Mechanical Engineering and Sciences. 2015;8:1367-75.

[29] Priyadarshini SN, Sivakumar DB. Waste heat recovery in cement plant. International Journal of Engineering Research \& Technology. 2014;3.

[30] ZERI. Waste heat recovery for power generation in dry cement production. SET at Work Good Practice: Zhejiang Energy Research Institute; 2010.

[31] Bekelle K. Gov't drafts cement industry development strategy. The Reporter. Addis Ababa2015.

[32] GlobalCement. Dangote to spend US\$450m on cement plant expansion in Ethiopia. Global Cement: Pro Global Media; 2015.

[33] Yisehak S, Mulugeta A, Yared H. Biomass energy for cement production: opportunities in Ethiopia. Capacity Development United Nations Development Programme in Eastern and Southern Africa pp. 2009:15-7. 
[34] Ramesh A. Assessment of energy conservation in indian cement industry and forecasting of $\mathrm{CO}_{2}$ emissions: Cochin University of Science and Technology 2012.

[35] Teka M. Energy policy of Ethiopia. 2006.

[36] Shanko M. Ethiopia's bioenergy market,target market analysis. Deutsche Gesellschaft für Technische Zusammenarbeit (GTZ) GmbH,; 2009.

[37] Bayray M, Mustefa A, Yohannes F, Kiros H, Haileslasie A, Gebray P, et al. Wind energy data analysis and resource mapping of geba catchment, north Ethiopia. Wind Engineering. 2013;37:333-46.

[38] Ayu TT. Energy audit and heat recovery system design for a dry type rotary kiln: The case of Messobo cement factory: Mekelle University; 2012.

[39] Engin T, Ari V. Energy auditing and recovery for dry type cement rotary kiln systems - A case study. Energy conversion and management. 2005;46:551-62.

[40] Virendra R, Kumar BSP, Babu JS, Kant DR. Detailed Energy Audit and conservation in a cement plant. International Research Journal of Engineering and Technology 2015;02.

[41] Weston KC. Energy conversion: West Publishing; 1992.

[42] Worrell E. Energy efficiency improvement and cost saving opportunities for cement making. An Energy Star Guide for Energy and Plant Managers. Lawrence Berkeley National Laboratory. 2008.

[43] Berhe H. Feasibility study for generation of electric power from WHRPG of the two kiln exhaust gases of Messebo cement factory. Mekelle: Mekelle University; 2012.

[44] Basham DL, Wright JW, Ferguson KI, Moy GW. Steam power plants - fossil fueled. U.S. Army Corps of Engineers. 2004. 